\title{
Translating Intangible Cultural Heritage in an Ethnolinguistic Community: A Case Study of the Site of Xanadu in Inner Mongolia*
}

\author{
Jinyu Liu \\ Inner Mongolia University, Hohhot, 010021, China
}

\begin{abstract}
Translation of intangible cultural heritage is an important part of translation studies. As one of the intangible cultural heritages in the world, the Site of Xanadu is a typical representative of Mongolian national history and splendid culture. The English translation of Xanadu's history and culture has to be idiomatic to foreign tourists, especially native English speakers. By a close study of English translation of Xanadu resources, this article attempts to discuss the current translation problems arising from application documents, advertisements and websites about Xanadu and reasons behind. Besides, the feasible translation strategies and methods are also suggested for better understanding between different cultures. The two functions of translating intangible cultural heritage, transferring of information and dissemination of culture, are particularly important, which play an important role in making Mongolian culture better understood by foreign visitors.
\end{abstract}

Index Terms - international publicity of intangible cultural heritage, the Site of Xanadu, translation problems, strategies of translation

\section{INTRODUCTION}

The intangible cultural heritage of Inner Mongolia incorporates a large number of historical sites and cultural properties, which is the first window for foreign visitors to learn about Mongolian culture. The external publicity of English translation of the intangible cultural heritage is an important means of dissemination of Mongolian history and culture to foreigners, which has the function of information transmission and cultural transmission.

As one of the intangible cultural heritages in the world, the Site of Xanadu is a typical representative of Mongolian national history and splendid culture. It attracts a great number of tourists worldwide annually. So the English translation of Xanadu's history and culture has to be idiomatic to foreign tourists, especially English-spoken ones. In order to achieve better efficiency of translation, translation practice needs more theoretical guidance. By a close study of English translation of Xanadu commentaries, this article attempts to discuss the current translation problems arising from application documents, media, advertisements and websites so on and so forth about the introduction of Xanadu. The reasons behind the problems and feasible translation strategies and methods are also discussed for better understanding between different cultures.

\section{A BRIEF INTRODUCTION TO XANADU}

The Site of Xanadu encompasses the remains of Kublai Khan's legendary capital city, designed by the Mongol ruler's Chinese adviser Liu Bingzhong in 1256. Located on the southeast edge of the Mongolian plateau, it was the first capital (1263-1273) of Kublai Khan and later the summer capital (1274-1364) of the Yuan Dynasty. With a surface area of over 25,000 ha., the Site of Xanadu was a site of a grassland capital, witnessing clashes and mutual assimilation between the nomadic and agrarian civilizations in northern Asia. It was also a unique attempt to assimilate the nomadic Mongolian and Han Chinese cultures. From Xanadu, the mounted warriors of Kublai Khan unified the agrarian civilizations of China, and was partly assimilated by the latter's culture, while extending the Yuan empire right across North Asia. From this base, Kublai Khan established the Yuan dynasty that ruled China over a century.

The site was planned according to traditional Chinese fengshui in relation to the nearby mountains and river. It features the remains of the city, including temples, palaces, tombs, nomadic encampments and the Tiefan'gang Canal, along with other infrastructures. Evidence of large water control works instigated to protect the city exists in the form of remains of the Tiefan'gan Canal. The city site and associated tombs are located on the grassland steppe with a north-south axis determined by traditional Chinese fengshui principles, backed by mountains to the north and a river to

\footnotetext{
* This paper marks a stage in a research that was made possible by the Philosophy and Social Sciences Research Planning Office of Inner Mongolia, China (program No.2011C027), and supported by the China National Committee of MTI Education (program No.MTIJZW201411) as well. I wish here to renew my thanks to both the committees that saw the interest of this research not only for the case study at hand, but for reflecting on a field of translation studies.
} 
the south. The plan of Xanadu, with Palace and Imperial cities enclosed partly by the Outer City containing evidence of the nomadic encampments and royal hunting enclosure, comprises a unique example of cultural fusion.

As the place where Kublai Khan rose to power, entertained foreign travelers' writings gave inspiration down the centuries. The Site has achieved legendary status in the rest of the world and it is the place from where Tibetan Buddhism expanded. The religious disputes that took place here resulted in the dissemination of Tibetan Buddhism over north-east Asia, and a cultural and religious tradition still practiced in many areas even today.

\section{Translation Practice: CuRrent Situation}

\section{A. Translation Situation of the Site of Xanadu}

The purpose of translation is to make the readers understand the original message accurately. To achieve this goal, translators should try to resolve the differences between the two languages in the aspects of style and logic. Guided by the target language, it means to make readers understand without meeting any obstacles in the process of getting information. If the language is the carrier of the culture, it seems to be more natural that the form and the content of the language are more anglicized since we are using English (Yuan, 2007). Many related problems are lack of correct understanding of English translation. The translation with Chinese is not for practical purpose, but to follow the fashion.(Lin, 2005, p.224) The current problems include lacking of current foreign consciousness, the readers' habits of thinking, information demand and other factors causing the disapproval of its audience and the failure of translation. Being influenced by the mode of thinking in Chinese, translators translate the surface information and ignore to convey the implicit information. The translation is not concise and translation of the cultural vocabularies of the source language is not good enough. Few translators take the readers' thinking habits, cultural elements and other differences into consideration. Another problem is an overuse of transliteration and non-specific translation.

\section{B. The Choice of Translation Strategies}

Vermeer, one of the founders of Skopos theory, thinks translation is to achieve the purpose of the recognition of a social activity. It must be put in the social system rather than a simple language processing in the system, where usually exists differences in the cultural environment between the readers and the original readers. Translators have the rights to use all sorts of different translation strategies to make the translation more acceptable. At this point, the original texts are raw materials. The translators can give up, restructure and process the passage according to the situation. Whether the translation can achieve the purpose or not is depending on the target readers' demand and acceptance of the text. In the cultural globalization, in addition to using complete translation strategies, the translators also adopt combination of strategies according to the specific requirements of the specific readers under certain conditions. Complete translation is a kind of thinking activity and interlingual activity in which readers mean to convert the source language culture information into the foreign culture information. Complete translation is to totally convey the content of the original text in the original form. The so-called combination of strategies is the activity of gaining the original content in which the translators adopt various translation methods according to the special needs of specific readers. The description of the translation strategy is not ruling translators to translate in a certain way, but to provide ideas for practitioners.

In this sense, compilation is a common translation strategy and method. The compilation is the combination of compiling and translating. This process is not word-by-word translation. The translators can output irrelevant things, and provide some necessary explanatory background materials for the words with Chinese characteristics. Nord points out that any translation version contains the ingredients of compilation and the compilation is an expression of Skopos theory. Samuel Mark considers compilation belongs to a kind of communicative translation and one of the most liberal translation forms. Its purpose is to make the translation have the same effects on the target readers as the original text on the original readers.

\section{TheORETICAL GUIDANCE}

\section{A. Properties of the Translation of Intangible Cultural Heritage}

Newmark (2001), the contemporary German translator and researcher, once argues that the translation of different texts should adopt different translation strategies. He divides the texts into three types, expressive texts, informative texts and vocative texts. He holds that expressive texts such as novels, poems and other literary works which are to introduce the source language culture, namely to try to convey the original semantic content, and to keep the writers personal emotional color, writing style and structure. Translators should adopt the semantic translation. For informative and expressive texts such as advertising, notices, reports, manual of tourism translation, translators should adopt the communicative translation method and pay necessary attention to readers' understanding and reaction. The translation should be in accordance with the texts in the target language habits as far as possible. The translation of intangible cultural heritage should be as the same as the translation of the world cultural heritage which are both to enhance English readers' understanding, attract the world's attention and gain protection, so the translation of intangible cultural heritage should belong to an informational and induced text, and its main task is to let foreigners understand Chinese intangible cultural heritage. 


\section{B. Identification}

This article advocates the principle of "identification" which is put forward by the American rhetorician Boke, and which can effectively guide the translation practice when translating the commentary of intangible cultural heritage, because as the creatures who exist independently in the world, in order to overcome isolation, human beings always find common identity in communication. In other words, the demand for identity comes from the opposition and differences. It is because the opposition and differences among people that people need to resolve differences through communication.(Foss, 2002, p.191-193). And the establishment of identification is the effective guarantee in the process of translation to realize the external publicity and achieve final understanding. In addition, the principle of identification is in accordance with the essence of Skopos theory and three closeness principles: close to the practice of Chinese development, close to a foreign audience demand for Chinese information, close to a foreign audience habit of thinking (Huang, 2004). Specifically, this principle refers to the translators who try their best to make the target language audience accept as much information as possible so as to maximize the acceptance of translations under the clear guidance of fundamental purpose.

\section{Cultural Property}

Culture is the material wealth and spiritual wealth created by human social and historical practice in general term. The unique cultural phenomenon of language is the essence of the national legal and economic matters, not only referring to the nation's contribution to the world, but also the foundation for survival and development of the nation. The fact that translation introduces the essence of the primitive culture into the target language culture will in a certain extent promote the development of the society, the nation's progress and the change of life. As is known to all, language is not only an organic part of culture, but also the important carrier of culture. Each language is the product of the development of national culture, containing its origin of the historical background and rich cultural connotations. Every country, every nation has its unique social system, ecological environment, religious beliefs and customs, etc., so that every language has its corresponding vocabularies, idioms, and allusions, such as "cultures-loaded words" responding to the cultural phenomenon. Culture-loaded words are also called vocabulary vacancy, which means that the cultural information carried by the original words has no corresponding words in the target language. In the process of translation, the translator should be original language-oriented, using literal translation, free translation, transliteration, meaning or supplementation and other flexible ways to keep national cultural characteristics and make every effort to achieve the real cultural facsimile.

\section{Strategies of Translation of the Site of Xanadu}

\section{A. Translation of Vocabularies}

\section{Translation of Geographical Vocabularies}

ST1. 地处蒙古高原的东南边缘，位于中华人民共和国内蒙古自治区锡林郭勒盟的正蓝旗和多伦县境内。

TT1. Situated in the southeast border area of the Mongolian Plateau, it is located in Zhenglan Qi and Duolun County, Xilingol League, Inner Mongolian Autonomous Region, P.R.C

According to the common translation of “盟”, “锡林郭勒盟” should be translated as Xilingol Prefecture. Prefecture means an area of local government in some countries such as France. But the translation should conform to the historical background at that time, and the Xilingol league does not have its own government. Its original purpose is that in order to consolidate its rule and regulations, the government held a sovereign meeting calling in all counties every three years. "League" refers to a group of people or nations who have combined for a particular purpose. It fully conforms to the original meaning, but not to the potential readers.

\section{Translation of Historical Vocabularies}

In the translation of specific historical and cultural words, if there are no corresponding words in the target language, transliteration and semantic translation are commonly used methods to maintain its culture.

ST2. 1260 年, 忽必烈在开平府登基称汗。

TT2. In 1260, Kublai Khan proclaimed himself Great Khan in Kaiping Fu.

ST3. 可以按照蒙古旧俗举行一系列蒙古宗王和贵族的宴会、狩猎、祭祀等活动。

TT3. To hold various activities according to Mongolian folk-customs, like gatherings of Mongolian kings and nobles, hunting, worship, etc.

These two examples contain some official names of Chinese Mongolian tribes and they have no corresponding words in the target language culture. The translations should reflect the Mongolian history and culture. In ST2. “汗” in Mongolian is Hagan-Haan, corresponding to western word Khaghan-Khan. While the translation of Great Khan without any related knowledge of history and culture, is unfamiliar to foreigners. Adding a note, the superior name of the governor of certain nationalities, such as Mongolian, would become easier for them to understand. In ST3. “宗王” is similar to the “亲王”. And in Qing dynasty, “亲王” is translated into first-grade prince, (qin wang). So translation of kings can't accurately convey the cultural meaning of the word. And it should adopt the method of semantic translation to maintain its culture.

\section{Translation of Cultural Vocabularies}


Translators should consider whether the translation can be easily understood and accepted from the perspective of the foreigners. In the context of Chinese culture, literal translation sometimes makes foreigners obscure. In this case, the translator can translate by adopting the combination of transliteration and explanation, which can both keep the Chinese characteristics and help foreigners to understand accurately.

ST4. 在城市选址方面既满足了蒙古游牧民族生活方式的要求，又符合中国聚落选址的“风水理论”。

TT4. In respect of city location, Xanadu not only satisfied demands of Mongolian nomadic life means, but also met Geomantic Theory for location selection of China.

When translating “风水”, Youdao (online translation website) just translated as "fengshui” without any further explanation. While the proper translation should be "Fengshui, which refers to the location of a person's house and ancestral grave supposed to have an influence on the fortune of a family and his off springs" And the "Geomantic" refers to the art of arranging buildings and areas in a good or lucky position. It is also appropriate. Only in this way, the unfamiliar Mongolian information can be fully understood and it is also in accordance with the identification.

\section{B. Translation of Phrases}

\section{Translation of Geographical Phrases}

ST5. “元上都遗址”是在都城规划方面具有蒙汉民族文化融合典范价值的中国北方草原都城遗址。

TT5. The Site of Xanadu is the site of an exemplary Chinese northern prairie capital which integrates the cultures of the Mongolian and Han nationalities in terms of capital planning.

ST6. 元上都城址的分布格局可分为城区（包括宫城、皇城、外城）、关厢和铁幡竿渠。

TT6. Layout pattern of Site of Xanadu contains urban area (Palace City, Imperial and Outer City), neighborhoods outside of city gates and Tiefan'gan Canal.

TT6. The city plan of the Site of Xanadu can be divided into city areas (including royal city, imperial city and outer city), Guanxiang areas and Tiefangan drainage.

"Guangxiang areas" cannot fully demonstrate what it is and what its function is. Target readers may only know the pinyin. Actually “关厢”refers to the nearby residents and areas. So it should be translated as "neighborhoods outside of city gates" by adapting the semantic translation method. The "Site of Xanadu" in TT5 is translated according to Mongolian usage.

In the translation of intangible cultural heritage, there are a lot of nationalistic terms which are totally unfamiliar to target readers. At this time, translators can use Chinese pinyin corresponding to Mongolian language with annotation to interpret the cultural terms.

ST7. 金莲川草原曾经是辽、金、元三代帝王的避暑胜地。

TT7. Xar Tala used to be the summer resort for the emperors of Liao, Jin (1115-1234), and Yuan dynasties.

ST8. 上都河被当地的牧民视作圣水。

TT8. Xandii Gool was regarded as sacred water by local herdsmen.( In Mongolian, it was called shangduyingaole. Gaole meant "river" in Chinese.)

In ST7, the origin of the Chinese 金莲川草原 has some background information.

Transliteration "Jinlianchuan Grassland" can only pass the literal meaning of the words to the reader, but the background information which it contains has to be lost. By adding the note, target readers will understand why they call this grassland Xar Tala and how beautiful it looks. They may strongly hope to see the grassland when they just read the translation. In ST8, the note gives supplementary information so that foreigners can understand the river in the form of Mongolian expression, and they can also be familiar with the corresponding Chinese pinyin.

In Chinese, the same meaning of words or phrases could have different translations in English, especially geographical terms, which requires that the translator in translating process pays attention to the local actual situation to choose the appropriate translation rather than simply giving the corresponding translation word by word.

ST9. 金莲川草原及反应当地理特征的沙地和湿地等独特的景观。

TT9. Jinlianchuan Grassland and the unique landscapes which reflect the geographic features of the city such as sandy land, wetlands.

TT9. Xar Tala, as well as featured sceneries reflecting geographical features of the city, like sandlot, marsh.

In the two kinds of translated text, “沙地”and “湿地”have two completely different translations. But “sandy land” refers to the surface of the sand covered including desert, basically no vegetation on the land, not including water system of the beach. The surface of the Mongolian sand includes a small part of the wetland. Hunshandake Sandlot is located at an arid and half-arid area; it has very obvious continental climate characteristics. Because of the arid and little rain, there is a strong windy weather. Flowing sand hills, half-fixed sand hills, fixed sand hills, lowland among the sand hills, marshes and Zhaoer exist among each other. This creates an unusual landscape of the sandlot. Marsh grassland mainly refers to Xandii Gool marsh in the south of the Site. It is a narrow area in an east-west direction. And the area of the heritage and buffer area is about 79 square kilometers. The water system of the marsh is composed by Xandii Gool and Grassland Lake. When Chinese globeflowers blossom in summer, the meadow is filled with yellow, white, purple, and pink flowers, presenting a unique grassland landscape of marshes. While if “湿地” is translated into "wetland”, it only refers to the an area of wet land, which means the land is covered with or containing liquid, especially water. So 
we should make the translation correctly reflect the message of the original text.

\section{Translation of Cultural Phrases}

In order to let the translation better understood by readers, the translator needs to consider the reader's background knowledge, by using different methods of translation to deal with a particular cultural phenomenon.

ST10. 随葬品出有灰陶盆、茶釉长瓶、黑釉瓶、双耳瓶、绿釉盖罐、釉陶香炉、白瓷碗、铁锈花罐、影青瓷 小碗、龙泉窑大碗、钧窑杯。

TT10. The burial objects were of various types: grey pottery basins, tea-colored glazed bottles with long neck, black glazed bottles, two-handled bottles, green glazed jars with lids, glazed pottery incense burners, white porcelain bowls, jars with rust pattern, small shadowy celadon bowls, big bowls produced by Longquan Kiln, cups produced by Jun Kiln.

In translation, appropriate use of means of appealing plays an important role in improving the rhetorical effect of the translation and it is very important to achieve the intended purpose of the translation (Yuan, 2007). In TT10, “茶釉长瓶 和双耳瓶” are translated into tea-colored glazed bottles with long neck, two-handled bottles. These translations are depending on the shape and outlook of the two items. If we just translate them in Chinese pinyin, target readers get no ideas about them, what they are like and why they are so named. “影青瓷小碗” is translated as small shadowy celadon bowls, which is more appropriate than being translated into shadow celadon bowls, because the latter is the combination of two words, shadow and celadon. The original meaning of “影” is shadowy, which is dark and full of shadows. It is somewhat related to the color.

\section{Translation of Sentences}

In the perspective of the sentence, due to different languages have different syntactic rules, in the process of translation sometimes translators need to rearrange a sentence order to make it more in line with the purposes and habits.

ST16. 自然环境包括与城市选址特征关系紧密的上都河、龙岗山和金莲川草原等自然要素, 以及反映城市地 理环境特征的沙地、湿地、森林草原和典型草原等特色景观; 人文环境包括遗产所在地保存完好的蒙古族传统 文化，以及城址周边分布于群山顶部的敖包所体现的草原游牧民族早期的山岳崇拜。

TT16. The natural environment contains natural elements closely related to location features of the city, like Xandii Gool, Longgang Hill and Xar Tala, as well as featured sceneries reflecting geographical features of the city, like sandlot, marsh, forest grassland and typical grassland; and the humanistic environment contains complete Mongolian traditional culture at the heritage site, and early mountain worship of the grassland nomadic nationality reflected by oboos distributed on tops of mountains around the city site.

In Chinese, all the attributives are before the nouns. And there are different processing methods when dealing with attributives more than a single word such as the present participle and the past participle.

In terms of vocabulary, there is the need for transformation of parts of speech, but they are not rigidly carried out in accordance with the original such direct translation.

ST17. 元代, 这种聚会成为皇帝赐予的燕飨, 凡新皇帝即位, 群臣上尊号, 册立皇后、太子, 以及每年元旦, 皇帝过生日, 祭祀, 春搜、秋狝, 诸王朝会等等活动, 都要举行宴会。

TT17. In the Yuan Dynasty, this assembly became a feast bestowed by the emperor. It would be held on occasions of most major events, including taking thrones, proposing of honorary titles to emperors by officials, crowning the empress, appointing the crown prince, celebrating New Year's Day and birthday of the emperor, holding sacrificial ceremonies, hunting excursions in the spring and the autumn and gathering of kings.

In these sentences, the verb phrases are all translated into noun phrases, which are more natural and more accustomed to the target readers' reading habits.

When the original information is too dense or difficult to understand, sometimes translators have to adopt the method of omission in the process of translation.

ST18. 宴会进行的时候, 宣读成吉思汗祖训, 有“喝戞”之礼, 设专人高呼“月脱”（意为“请用”）, 大家敬酒。

TT18. On the banquets, the maxims of Genghis Khan would be read aloud and people would toast to each other.

Translators' subjectivity is that the translators as the subjects change and control the translation in the translation activities and it is also one of the characteristics of the original text's service for the translators (Liu, 2010). Translators can have certain subjectivity; and translation of intangible cultural heritage also has certain advantages. The text is not "the static text" (Chen, 2006). This sentence contains dense culture information. Making it clear to potential readers needs annotations and interpretations. For this kind of dense message, omission may be a more appropriate method. In translation, information about the Mongolian cultural vocabulary (“喝盛”) is omitted.

\section{CONCLUSION}

By stimulation of economic globalization, the world has entered into the communication of globalization. The main content of the global communication is the international information dissemination. In the global wave, only by strengthening the publicity and information exporting, one country could let other countries know it so that its own culture can be integrated in cultural exchanges and be promoted to the outside world. This can also make the 
information exporting countries better understood so as to reduce or avoid conflicts among countries. The importance of propaganda also highlights the importance of translation. In Inner Mongolia, intangible cultural heritage contains a large number of historical and cultural information which is one of the important ways to understand Mongolian people for foreigners. It is necessary for the local government to strengthen the translation to move towards the world in the fierce competition of the world cultural diversity. Only in this way, the broad and profound Mongolian culture can be recognized by the world. Translation can be defined as a kind of cross-cultural communication activity in a pretty high level. As the intangible cultural heritage protection has a lot of confusion, the translation of the intangible cultural heritage is also a heavy task (Dai, 2005). There are several translation requirements. First of all, historical information should be highlighted. Second, the translation should be accurate and authentic. Of course, translators should choose appropriate translation strategies. Both the interpretations of the translators and the readers are not expected to have any deviation in order to form correct and effective translation and even to help the readers have correct cultural associations. The original purpose of translation is to let foreigners understand. Due to different historical and cultural backgrounds, the translator should bear in mind that in the process of translation, there is a difference between internal propaganda and translation for global purpose. When translating between two languages, the primary task of the translator is to convey information, rather than just a language translation. Translators must seriously consider the characteristics of the two languages, cultural differences, and adopt different translation methods for different problems so that they can achieve the same reading effect.

\section{REFERENCES}

[1] Chen, M. (2006). External Influences and Construction of Translator Subjectivity: Translation of Bible as a Case Study. Foreign Languages and Teaching, 6, 50-53.

[2] Chen, X.W. (2007). Identification as a Principle in Translating Materials for International Publicity. The Chinese Translator, 1, $60-65$.

[3] Chen, X.W. (2008). Pragmatics and Application of Language Resources in Translation. The Chinese Translator, 6, 55-59.

[4] Dai, L. (2005). Problems in Protection of Intangible Cultural Heritage. Perspective, 7, 57-59.

[5] Foss. S.K et. Al. (2002). Contemporary Perspective of Rhetoric (3rd ed.). Prospects Heights: Waveland.

[6] Huang, Y.Y. (2004). Stick to Three Principles to Deal with Problems in International Publicity Translation. The Chinese Translator, 6, 27-28.

[7] Lin, D.J. (2005). Transcultural Communications: Theory and Practice. Fuzhou: Fuzhou People's Press.

[8] Liu, X.Q. (2010).Transliteration and Translatability. China Science Translation, 2, 37-39.

[9] Newmark, P. (2001). A Textbook of Translation. Shanghai: Shanghai Foreign Education Press.

[10] Yuan, X.N. (2005). Reasons and Strategies of International Publicity Translation. The Chinese Translator, 1, 75-78.

[11] Yuan, X.N. (2007). On Some Problems of International Publicity Translation. The Chinese Translator, 6, 88-89.

[12] Zhou, L.S. (2007).Translator Subjectivity in Language. Shanghai University Journal, 2, 120-127.

Jinyu Liu, Ph.D, Associate Professor in the English Department of the Foreign Languages College, Inner Mongolia University, China. Her academic interest includes Inner Mongolian translation history, pedagogy and training, East Asian translation history. 